\title{
Prey harvests of seabirds reflect pelagic fish and squid abundance on multiple spatial and temporal scales
}

\author{
W. A. Montevecchi ${ }^{1}$, Ransom A. Myers ${ }^{2}$ \\ ${ }^{1}$ Departments of Psychology and Biology, and Ocean Sciences Centre, Memorial University of Newfoundland, St. John's, \\ Newfoundland, Canada A1B 3X9 \\ ${ }^{2}$ Science Branch, Department of Fisheries and Oceans, PO Box 5667, St. John's, Newfoundland, Canada A1C 5X1
}

\begin{abstract}
Many studies have demonstrated relationships between seabird prey harvests and fisheries catches. These correlations have for the most part been found at scales from 10s to 100 s of kilometers within foraging ranges around seabird breeding colonies. In the present study, we investigated associations between the prey harvests of northern gannets Sula bassana at a large breeding colony off the northeast coast of Newfoundland and the catches of the inshore Newfoundland fishery at different spatial scales and time intervals. Significant correlations occurred between the seabirds' and the humans' catches of mackerel Scomber scombrus and short-finned squid Ilex illecebrosus from 1977 through 1992. The relationships for squid were stronger over larger geographic areas than were those for mackerel. The associations for both squid and mackerel reflected abundance/availability around the colony, at a larger scale near the gannets' maximum foraging range (e.g. $\sim 200 \mathrm{~km}$ ), and for the entire Newfoundland region (1000s of kilometers). These correlations were significant at August vs August and August vs annual time intervals. The gannets' landings of squid were also associated with fishery-independent, research survey indices of squid abundance over thousands of kilometers. The robustness of these relationships indicates that levels of pelagic prey harvest by seabirds can provide reliable indices of prey abundance within and outside reproductive seasons and foraging ranges around breeding colonies. Similar relationships are predicted between seabird and human fisheries that are directed at migratory 'warm-water' pelagic prey that move into cold and high latitude oceanographic regions.
\end{abstract}

KEY WORDS: Bio-indication · Pelagic food webs · Seabirds · Trophic relationships

\section{INTRODUCTION}

Owing to patchy distributions and high mobility, it is difficult to survey and to estimate accurately abundances of pelagic fishes and invertebrates (e.g. Clarke 1977, Stobo et al. 1982). Fishery-independent estimates of the abundances of pelagic organisms based on acoustic, egg and larval surveys are rare and relatively unreliable (e.g. Hurley 1980a, Dawe \& Beck 1985). Even when it is possible to locate pelagic prey on surveys, the schools of many species occur in 'hydroacoustically invisible' surface waters and also avoid ships (Diner \& Masse 1987).

Dietary, energetics, behavioural and production data collected from seabirds have been used to derive indices of prey abundance that can be incorporated into multi-species assessment models (e.g. Croxall 1989, Monaghan et al. 1989, Barrett et al. 1990, Bailey et al. 1991, Hatch \& Sanger 1992, Montevecchi 1993, see also Lilly 1991). Interannual variation in the abundances of pelagic fishes and squids is often reflected in the prey harvests of seabirds (e.g. Hislop \& Harris 1985, Montevecchi et al. 1987). Typically, these relationships are assumed to exist within avian foraging ranges around breeding colonies on scales of $10 \mathrm{~s}$ to 100s of kilometres (Hunt et al. 1991). However, correlations between local prey harvests by seabirds at breeding colonies and large-scale variation in pelagic fish abundance indices have been reported. For example, parental food harvests by Atlantic puffins Frater- 
cula arctica on the Isle of May (Scotland) have been shown to be strongly correlated with larval indices and abundances of herring Clupea harengus and sprats Sprattus sprattus in the North Sea (Hislop \& Harris 1985). Relationships like these can be used to monitor the abundance of pelagic fishes. Such bio-assays will be more useful if the prey harvests of seabirds reflect more than local, transitory fluctuations in prey populations (Hunt et al. 1991).

The prey harvests of northern gannets Sula bassana and cape gannets $S$. capensis are known to correlate with inter-annual meso-scale $\left(10^{2} \mathrm{~km}\right)$ fluctuations in fisheries catches of pelagic fishes and squids (Montevecchi et al. 1987, Montevecchi \& Berruti 1991, Klages et al. 1992). In the present paper, we examine the spatial and temporal relationships between fisheries and seabird catches of mackerel Scomber scombrus and short-finned squid Illex illecebrosus. Both mackerel and squid are 'warm-water' pelagic species that migrate into the Northwest Atlantic during summer, when they are primary prey of breeding gannets (Montevecchi et al. 1984). Fishery catches of these species in the Newfoundland region occur mainly in late summer and early autumn. We compare a $15 \mathrm{yr}$ data set of the landings of mackerel and squid by gannets during August in a large colony $60 \mathrm{~km}$ off the northeast coast of Newfoundland, Canada, to fisheries catches of these species during August and during annual intervals on spatial scales of 10 s to 1000 s of kilometres. We also compare squid landings by gannets with fisheryindependent indices of the abundance of squid to assess if seabird data reflected abundance as well as availability to birds and fishermen.

\section{METHODS}

From 1977 through 1992, a total of 4474 food samples were collected during August (and rarely during July; Table 1) from gannets in the colony on Funk Island $\left(49^{\circ}\right.$ 45' N, 53 11' W; Fig. 1, see Montevecchi \& Tuck 1987). Food samples were obtained by approaching birds in the colony and at roosts. Gannets regurgitate food to chicks and often regurgitate loads at the approach of a researcher and before fleeing. Chicks behave similarly. Samples obtained from adults were often fresh, i.e. eyes intact, and almost always identifiable to species in the field. Fresh samples were weighed with Pesola spring scales, and their fork, total and/or mantle lengths measured. The frequencies of prey in the landings by gannets were converted to biomass on the basis of the mean masses of fresh prey items. Comparisons were made using Spearman rank-order correlations and Pearson product-moment correlations of the percentages of biomass $[\log (\%$ catch +1$)]$ of differ- ent prey with the tonnages of commercial catches $[\log ($ catch +1$)]$ during August and for entire years.

Data of fishery catches in different NAFO (Northwest Atlantic Fisheries Organization) areas and subareas were obtained from the Statistics Branch, Department of Fisheries and Oceans, St. John's, NF. Equivalent data do not exist for the other major prey species. In the Newfoundland region, neither mackerel nor squid have been under effective quota regulation, whereas capelin Mallotus villosus and herring Clupea harengus are under quota regulation. There is no commercial fishery for Atlantic saury Scomberesox saurus.

Inshore commercial catch probably provides a reasonable index of the level of mackerel and squid abundance for each subarea for which there is a substantial fishery (see Black et al. 1987), even though commercial catch is rarely a linear function of actual abundance and is heavily influenced by market demands. There has been a relatively constant number of fishermen in the pelagic fishery during the period of study, i.e. the number of full-time fishermen in Newfoundland from 1981 to 1992 varied from a minimum of 13351 to a maximum of 14619 (Donahue 1993). The main source of nonlinearity is likely that at high harvest levels, when catch is limited by the saturation of markets and processing capacity of fish plants.

We also considered estimates of the abundance of squid derived from research surveys to determine if the gannet harvest reflected prey abundance, and not only prey availability to birds and fishermen. We derived estimates of squid abundance from research surveys using bottom trawl gear designed to estimate

Table 1. Dates of collections and numbers of food samples collected from northern gannets Sula bassana on Funk Island, off Newfoundland, Canada

\begin{tabular}{|llc|}
\hline Year & Dates & No. of samples \\
\hline 1977 & Jul 12 & 105 \\
1978 & Aug 11-20 & 241 \\
1979 & Jul 31-Aug 6 & 163 \\
1980 & Aug 1-13 & 219 \\
1982 & Aug 9-13 & 196 \\
1983 & Aug 5-13 & 498 \\
1984 & Aug 9-19 & 289 \\
1985 & Aug 4-10 & 184 \\
1986 & Aug 7-15 & 494 \\
1987 & Aug 22-26 & 145 \\
1988 & Aug 12-20 & 525 \\
1989 & Aug 21-26 & 379 \\
1990 & Jul 18, 31-Aug 11 & 341 \\
1991 & Aug 12-16 & 406 \\
1992 & Aug 5-10 & 289 \\
$1977-1992$ & & 4474 \\
\hline
\end{tabular}




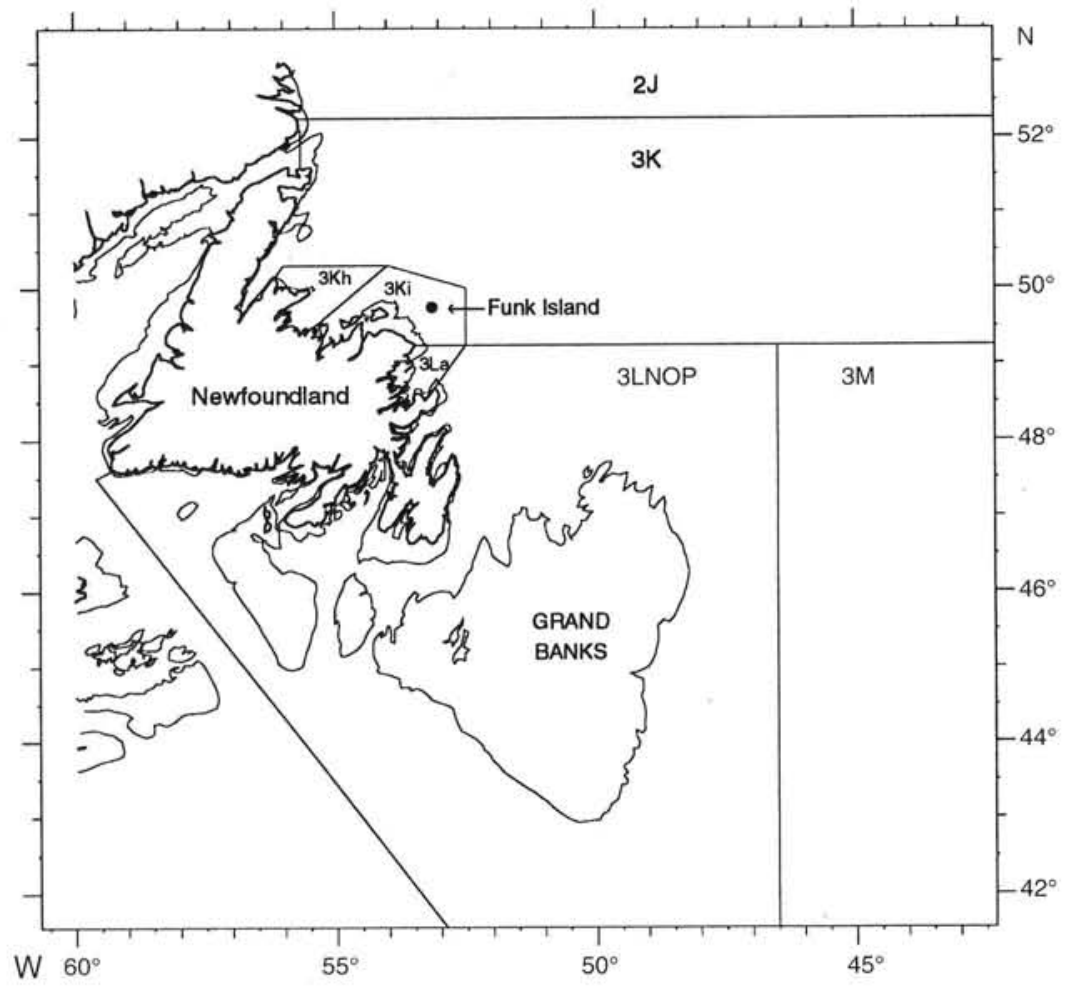

Fig. 1. Location of Funk Island and NAFO fisheries areas from which commercial catches of squid Illex illecebrosus and mackerel Scomber scombrus are compared with the prey landings of gannets Sula bassana. $3 \mathrm{Ki}=$ Funk Island Region; $3 \mathrm{Kh}, 3 \mathrm{Ki}, 3 \mathrm{La}=\mathrm{NE}$ Newfoundland; $2 \mathrm{~J}, 3 \mathrm{~K}$ to $3 \mathrm{P}=$ Newfoundland Region. The $100 \mathrm{~m}$ isobath is also shown

groundfish abundance. These survey trawls catch squid incidentally. Furthermore, the surveys in the northern part of the Newfoundland region (NAFO Divisions $2 \mathrm{~J}, 3 \mathrm{~K}, 3 \mathrm{~L}$ ) take place later than the period of maximum squid abundance, i.e. in October and November. The surveys in the other Newfoundland regions (NAFO Divs. 3N, 3O, 3P) occur during spring before the period of maximum squid abundance [see Hutchings et al. (1993) for a description of these surveys]. We also used summer groundfish surveys on the Scotian Shelf (NAFO Divs. 4X, 4W, 4VN, 4VS). These use a different trawling gear that appears to be better at capturing squid (Doubleday \& Rivard 1981). The mean number of squid caught per tow on these surveys was used as an index of abundance for the Scotian Shelf. Overall, we generated abundance indices for each of the 10 NAFO divisions listed above (see Table 2 ). We were unable to find or generate any fisheryindependent estimates of the abundance of mackerel.

Two approaches were used to examine the spatial scale over which gannet diet was providing information on relative abundance of prey. First, we correlated gannet landings at Funk Island with commercial catch at 12 coastal fishing zones around insular Newfound- land. We determined the region over which the correlation of gannet harvest at Funk Island was homogeneous, i.e. we asked if the correlations could be considered as samples from a population exhibiting a common correlation (Sokal \& Rohlf 1981, p. 587). If we could reject the hypothesis of no heterogeneity among the correlation coefficients, we then determined which correlations were different from the 'local correlation', i.e. the correlation of gannet landings at Funk Island with the local catch from Div. 3Ki (Fig. 1). A significance level of 0.05 was used. We examined all statistical subdivisions from Labrador around the coast of Newfoundland to the southwest tip of the island. The catches of squid and mackerel in Labrador and the southwest region of Newfoundland were too small to yield reliable correlations, e.g. there were fewer than 6 years in which squid and mackerel were caught. All other subdivisions were used in analyses.

The second approach we used was to combine commercial catch data over 3 spatial scales: (1) the colony vicinity (Funk Island region: Div. 3Ki), (2) larger meso-scale regions around the colony within avian foraging ranges (NE Newfoundland: Divs. 3Kh, $3 \mathrm{Ki}, 3 \mathrm{La}$ ), and (3) the fishing regions of Labrador, Newfoundland and St. Pierre et Miquelon (Newfoundland: Divs. 2J, 3K to 3P) (Fig. 1). The spatial scales of these regions can be approximated as the distance between the headlands used to define each of the coastal fishing areas. Using this criterion, the spatial scale of the Funk Island Region is $140 \mathrm{~km}$, NE Newfoundland is $310 \mathrm{~km}$, and the Newfoundland region is $1400 \mathrm{~km}$.

\section{RESULTS}

\section{Seasonal variation in pelagic prey availability}

Most of the major prey species that gannets feed to their chicks tend to prefer 'warmer' water and migrate into the Northwest Atlantic in late summer, when fisheries catches of these species are highest (Fig. 2). The seasonal pattern of catches varies among the 4 major pelagic species that are commercially exploited in the region. Short-finned squid and mackerel are summer migrants, and maximum catches are made during late 


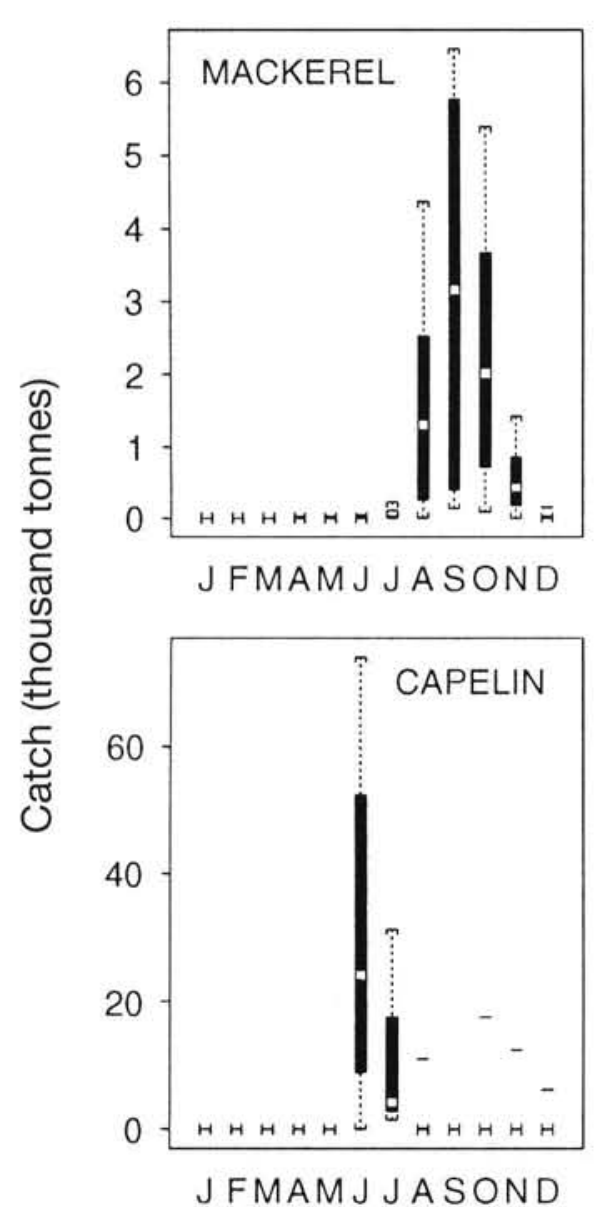

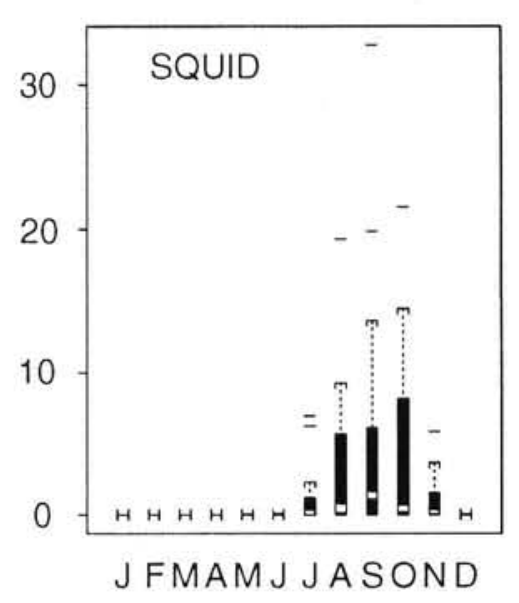

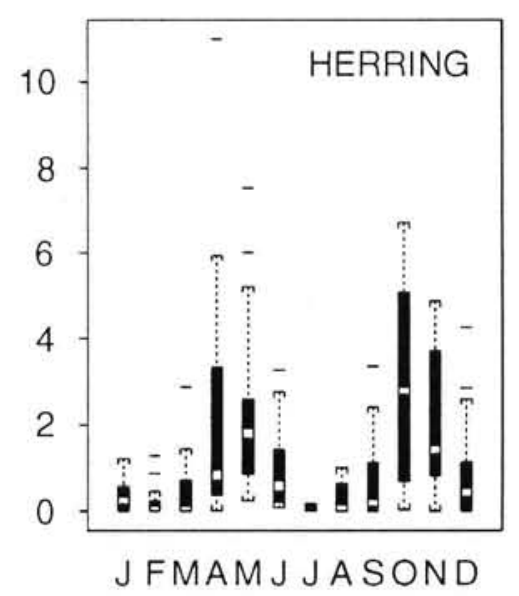

Month

Fig. 2. Box plots of the seasonal patterns of fishery catches of mackerel Scomber scombrus, squid Illex illecebrosus, capelin Mallotus villosus, and herring Clupea harengus in the Newfoundland region, which show the ranges (within brackets), quantiles (black bars), medians (white portion of bars) and outliers (dashes, defined as points that are further away from the median than 1.5 times the inter-quartile range) for the monthly catches from 1977 to 1991 summer and early autumn when annual sea surface temperatures are highest. Another 'warm-water' species, Atlantic saury, also moves into the region in some years in late summer, but is not commercially exploited. Herring in the region usually occur inshore, and commercial exploitation is targeted mainly at spring spawning schools and at autumn feeding concentrations. Capelin is a cold water species, and inshore catches are made in early summer during the spawning migration from offshore regions. Large variation in the commercial catches of pelagic species is evident (Fig. 2); in some years there are very large catches, while in other years practically nothing is caught. Overall, the temporal patterns are relatively robust.

\section{Relating gannet harvest to fishery-independent abundance estimates}

The gannets' landings of squid were correlated with research vessel indices of abundance over a wide oceanographic area (see Fig. 3). The correlations were high with the research vessel data off the Labrador coast (Div. 2J) and St. Pierre Bank (Div. 3PS), and the northeastern portion of the Scotian shelf (Divs. 4VN, 4VS; Table 2). The correlations with the Grand Bank region (Divs. 3K, 3L, 3N, 3O) were positive, relatively low and nonsignificant. The only negative correlation occurred on the central Scotian Shelf (Div. 4W). This analysis was repeated using Spearman's rank-order correlation in place of the Pearson product-moment correlation, and in all cases the correlations and significance levels were similar. The low correlations with the Grand Banks surveys may have resulted because the bulk of the squid caught are on the edge of the bank, and because catches depend greatly upon micro-scale variability in bottom temperature (Dawe \& Warren 1992). The variability in the research survey data is many times that seen in the gannet data, and it is clear that gannet landings are not proportional to squid abundance estimates. 


\section{Scaling of associations between catches of mackerel and squid by seabirds and humans}

Associations between the landings of squid and of mackerel by gannets at Funk Island and by inshore fisheries were broadly and highly correlated at the scale of large bays in the vicinity of Funk Island, both at the scale of more distant large bays and inshore regions around the Newfoundland coast and at the scale of the Newfoundland region as a whole (Figs. 3, $4 \& 5$ ).

Squid had a much wider range of association between seabird and fishery catches than did mackerel (Fig. 5). We could not reject the null hypothesis of no heterogeneity among the correlations for squid $\left(\chi^{2}=\right.$ $0.6, \mathrm{df}=11, \mathrm{p}=0.99$ ). There was, however, evidence that the correlations for mackerel are heterogeneous $\left(\chi^{2}=20.7, d f=12, p=0.05\right)$. The spatial scale for which the gannets' food samples provide information about commercial catch of mackerel is limited to eastern Newfoundland. For both mackerel and squid the strongest associations were found along Newfoundland's northeast coast in the general vicinity of Funk Island. Overall, avian and human harvests of mackerel and squid were highly correlated at local, meso and regional spatial scales in August vs August and in August vs annual comparisons (Figs. 6 \& 7). The above analysis was repeated using Pearson product-moment correlation. The only difference was that the local correlations were higher for mackerel, though still smaller than the larger scale correlations.

These data series were autocorrelated. For example, for the gannets' harvest of squid, the lag-1 autocorrelation is 0.58 , while for mackerel it is 0.43 . This effectively reduces the number of degrees of freedom in the analysis. However, even when the number of degrees of freedom is reduced by the method of Bayley \& Hammersley (1946), the results remain significant. A further check on the robust-

Fig. 3. Landings ( $\%$ of total mass) of shortfinned squid Illex illecebrosus by gannets Sula bassana on Funk Island, catches ( $\mathrm{t}$ ) by inshore fisheries in the Funk Island region (catch $\times 10$; 'Funk $10^{\prime}$ ) and the Newfoundland region ('NF'), and research vessel indices in mean catch per tow for NAFO Divisions $2 \mathrm{~J}, 3 \mathrm{~K}, 3 \mathrm{~L}$, $3 \mathrm{~N}, 3 \mathrm{O}, 3 \mathrm{P}, 4 \mathrm{VS}$ and $4 \mathrm{VN}$. All data have been transformed by $\log (\mathrm{catch}+1)$
Table 2. Correlations of landings of squid by gannets Sula bassana on Funk Island with research vessel indices of abundance. NAFO divisions are given in Fig. 1 and also include the St. Pierre Bank (3PS), the northeastern portion of the Scotian Shelf (4VN, $4 \mathrm{VS})$, the central Scotian Shelf $(4 \mathrm{~W})$ and Brown's Bank on the southwestern portion of the Scotian Shelf $(4 \mathrm{X})$. n: years of data

\begin{tabular}{|lllr|}
\hline $\begin{array}{c}\text { NAFO } \\
\text { division }\end{array}$ & $\mathrm{r}$ & $\mathrm{p}$ & $\mathrm{n}$ \\
\hline 2J & 0.57 & 0.02 & 14 \\
3K & 0.33 & 0.27 & 13 \\
3L & 0.32 & 0.24 & 15 \\
3N & 0.24 & 0.24 & 14 \\
3O & 0.26 & 0.39 & 14 \\
3PS & 0.71 & 0.03 & 9 \\
$4 \mathrm{VN}$ & 0.80 & 0.003 & 15 \\
$4 \mathrm{VS}$ & 0.73 & 0.002 & 15 \\
$4 \mathrm{~W}$ & -0.13 & 0.65 & 15 \\
$4 \mathrm{X}$ & 0.36 & 0.18 & 15 \\
\hline
\end{tabular}
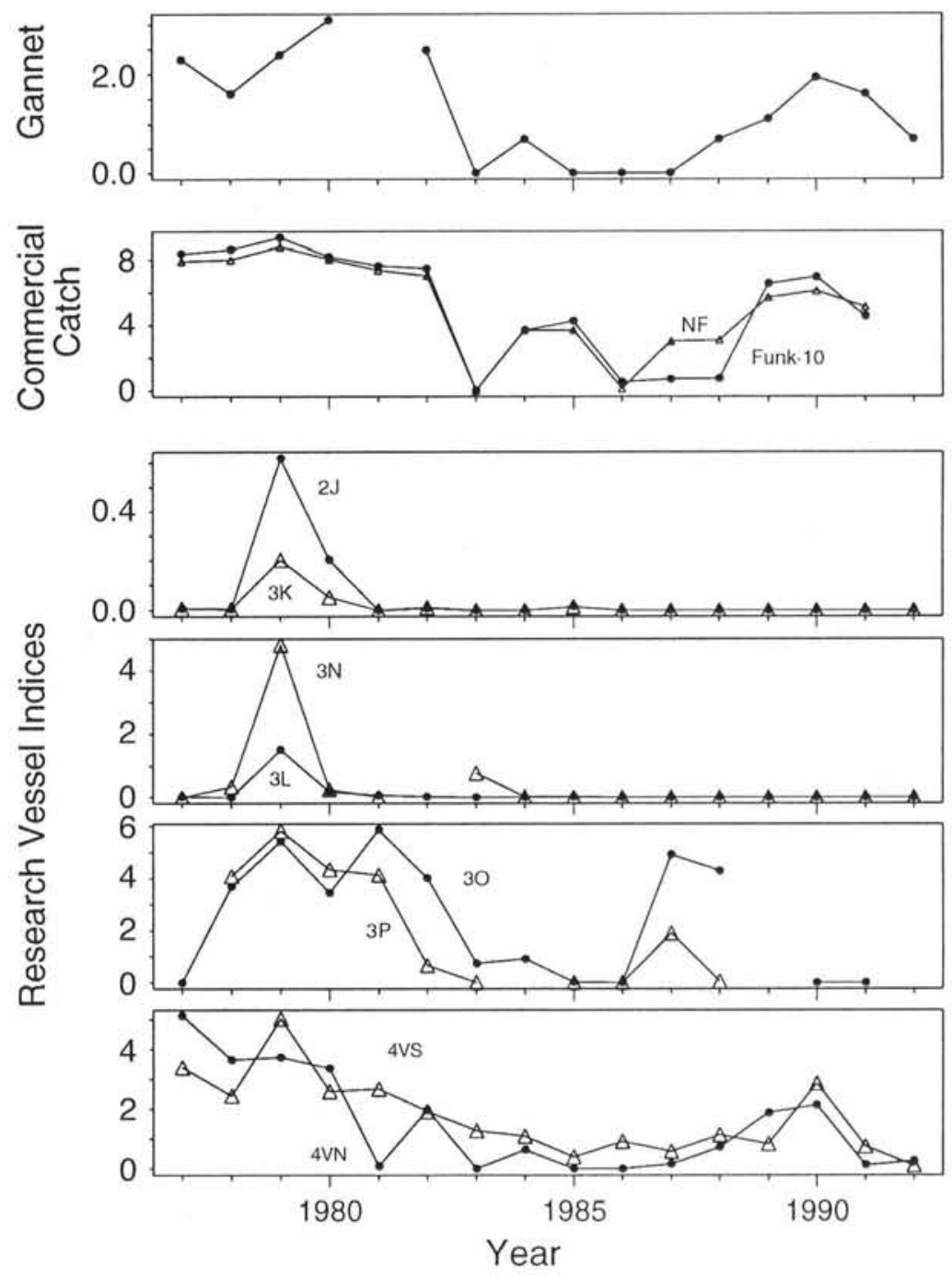

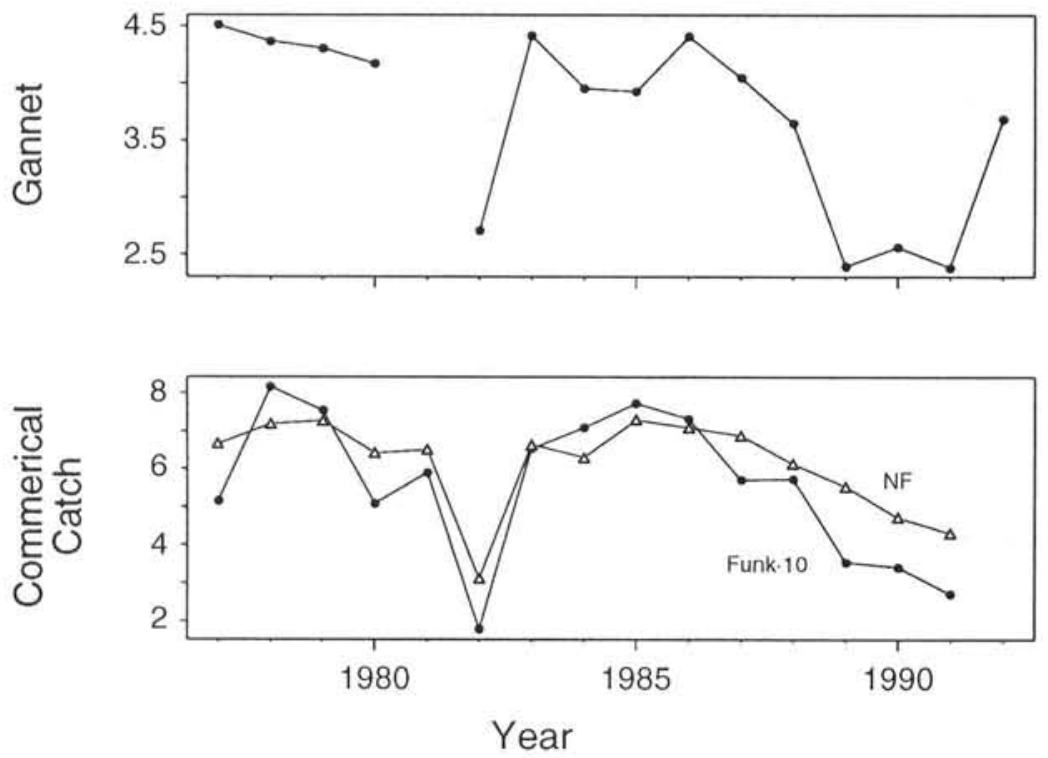

Fig. 4. Landings ( $\%$ of total mass) of mackerel Scomber scombrus by gannets Sula bassana on Funk Island, catches (t) by inshore fisheries in the Funk Island region (catch $\times 10$; 'Funk $10^{\prime}$ ) and for the Newfoundland region ('NF'). All data have been transformed by $\log ($ catch +1$)$

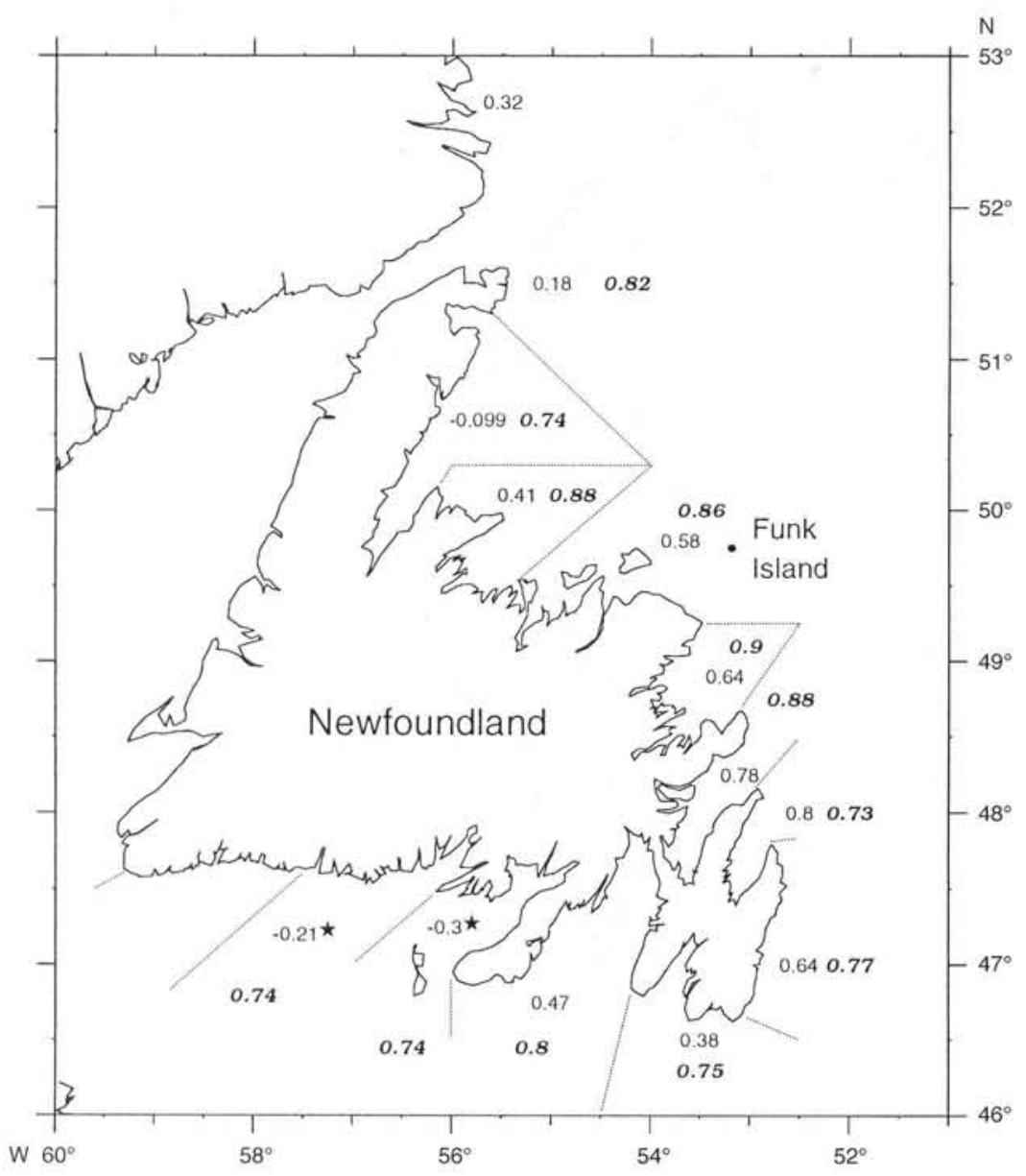

ness of the associations is to divide the annual time-series into 2 , an early and late section, and repeat the analysis. The strength and significance of the correlations increased for almost all cases, demonstrating the strength of the relationships.

\section{DISCUSSION}

The prey landings of gannets at 1 breeding colony, sampled once each year over a 5 to $13 \mathrm{~d}$ sampling period in late summer, reflected fishery catches of the birds' major prey species on spatial scales up to 1000 s of kilometres in extent. The seabirds' prey landings were associated with commercial fishery landings in August and with annual fishery landings; the seabirds' harvests of squid were also associated with fisheryindependent indices of the abundance of squid over spatial scales of 1000 s of kilometers. The robustness of these correlations is indeed striking. These findings support contentions that dietary data from seabirds are useful in predicting fishery conditions in local and meso-scale areas around breeding colonies (e.g. Montevecchi et al. 1987) and also in larger mega-scale regions beyond avian foraging ranges around colonies (e.g. Hislop \& Harris 1985).

Why do we find strong correlations between the prey harvests of seabirds and of humans at spatial scales much larger than the gannets' foraging range and at monthly and

Fig. 5. Spearman rank-order correlations between the catches of squid Illex illecebrosus by gannets Sula bassana in August and the annual catches of squid by the fishery (bold italic type), and between the catches of mackerel Scomber scombrus by gannets in August and the annual catches of mackerel by the fishery (plain type), in Newfoundland bays and inshore fisheries regions. Correlations that are significantly different from the local correlation around Funk Island are marked with asterisks 
Fig. 6. Relationships between the percentage of short-finned squid Illex illecebrosus in the prey harvests of gannets Sula bassana (log scale) and commercial catch (log scale) in the Funk Island Region (NAFO Div. 3Ki), NE Newfoundland (Divs. 3Kh, 3Ki, 3La) and Newfoundland (Divs. 2J, 3K to 3P), 1977 to 1992
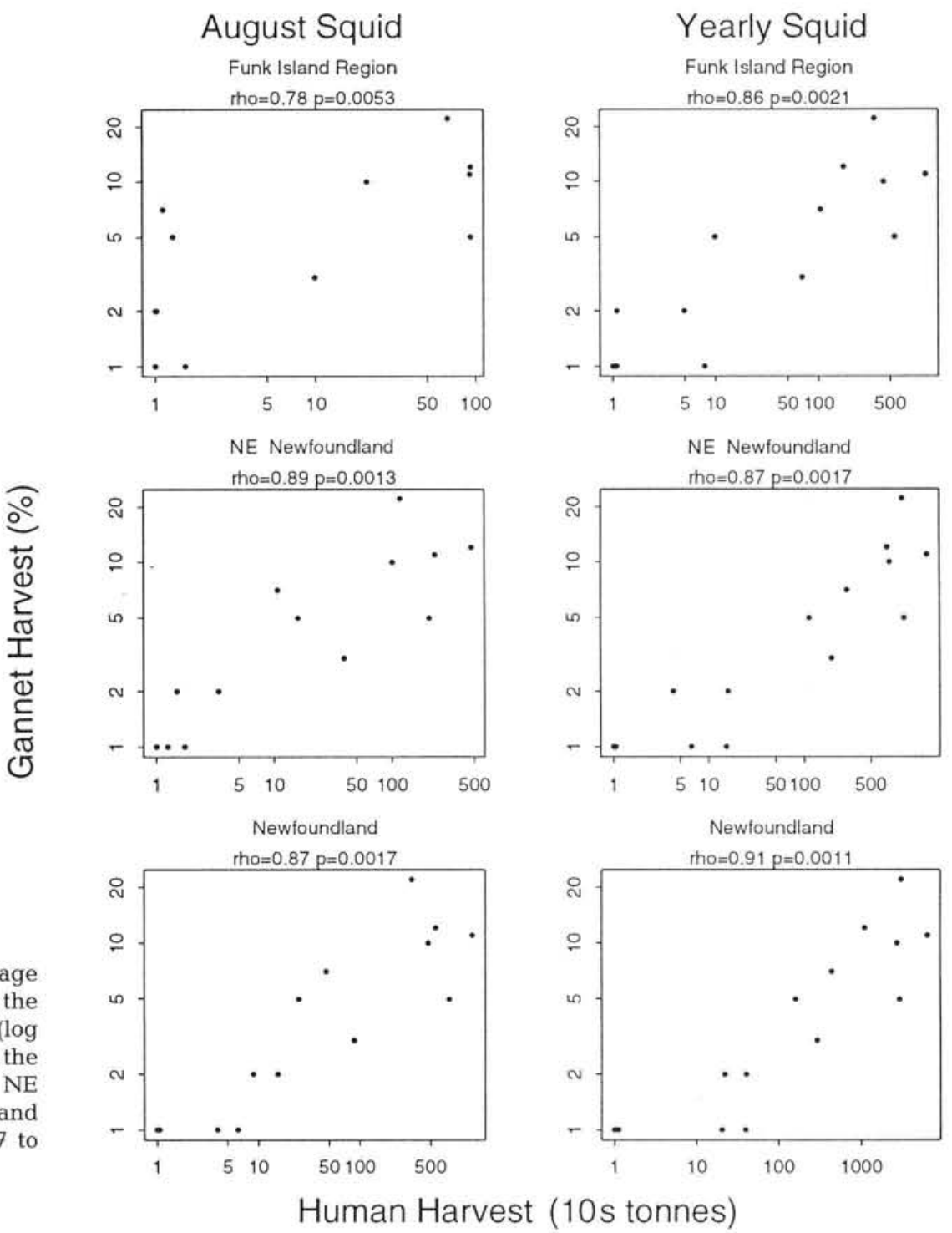

annual intervals that are longer than the seabird sampling period? These associations are not expected, because biotic and physical oceanographic interactions exhibit scale-dependent relationships (Hunt \& Schneider 1987, Barry \& Dayton 1991), and because pelagic food webs and the diets of conspecific seabirds often vary in different oceanographic regions (e.g. Schneider \& Hunt 1984) and through time (Vermeer \& Westrheim 1984, Duffy et al. 1987, Montevecchi \& Myers 1992). Some explanation lies in the interaction of the biology of the prey and the spatial scale of environmental forcing. Atlantic mackerel and short-finned squid prefer water temperatures in the range of 9 to $12^{\circ} \mathrm{C}$ (Squires 1957, Hurley 1980b, Scott \& Scott 1988), and the northward migration of these species was probably limited during summers with low catches of mackerel and of squid (Templeman \& Fleming 1953,
Parsons 1970). Sea surface temperature varies on scales of 1000 s of kilometers (Thompson et al. 1988), and the relationships over the space and time scales reported here may be caused by interactions of the thermal preferences of mackerel and squid with largescale variations in sea surface termperatures. Variations in Gulf Stream strength (e.g. Drinkwater et al. 1994) may influence sea surface temperature which in turn may affect pelagic prey migrations into the Newfoundland region from more southerly regions. When waters are warm enough for migration into the Newfoundland region, mackerel and squid, if abundant, radiate over a very wide oceanographic area, such that sampling at a single point (seabird colony) in space and time provides a robust signal of a very broad-scale pattern. The biological significance of these relationships derives from interactions between mega-scale 

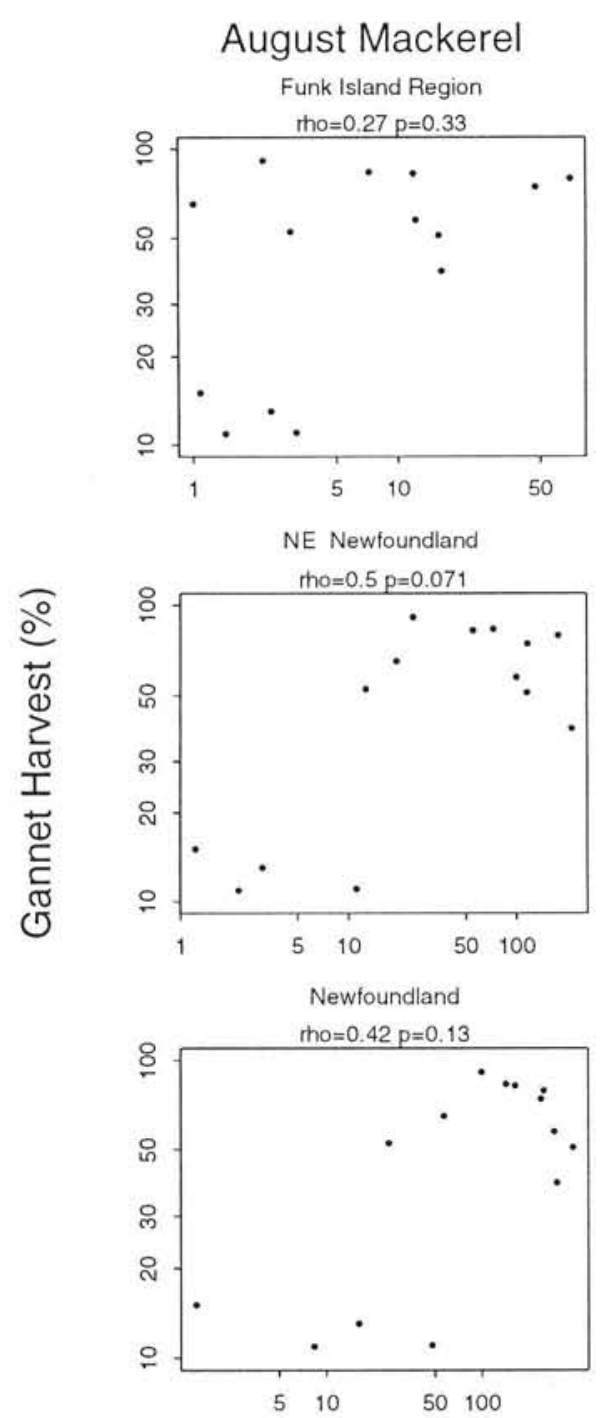

Human Harvest (10s tonnes)
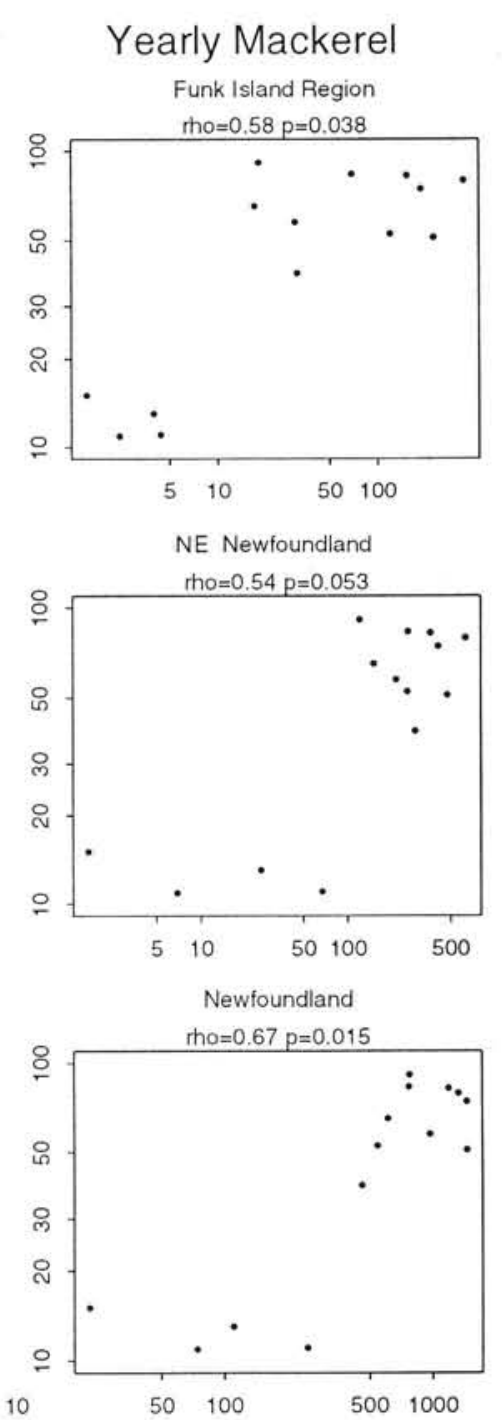

Fig. 7. Relationships between the percentage of mackerel Scomber scombrus in the prey harvests of gannets Sula bassana (log scale) and commercial catch (log scale) in the Funk Island Region (NAFO Div. 3Ki), NE Newfoundland (Divs. 3Kh, 3Ki, 3La) and Newfoundland (Divs. 2J, 3K to 3P), 1977 to 1992 physical events (surface water temperature) and biological responses (migratory movements) by pelagic squids and fishes. Similar relationships are predicted for many pelagic prey that migrate long distances into cold and high-latitude oceanographic regions (Coelho 1985). Large-scale biophysical associations and signals such as these (see also Aebischer et al. 1990, Bertram \& Kaiser 1993, Mann 1993) will be informative to marine ecologists and oceanographers studying environmental change and the dynamics of marine food webs.

Acknowledgements. We thank N. Barrowman, S. Bown, D. Butler, D. Cairns, V. Friesen, J. Russell and P. Ryan for analytical and field assistance. We thank G. Hunt, J. Parrish, D. Schneider and 3 anonymous reviewers for helpful comments on the manuscript. E. Dawe provided advice on the analysis of the squid data, and J. Simon provided the Scotian Shelf squid data. We thank the Newfoundland and Labrador Parks Divi- sion, Department of Tourism and Development, for permission to work on Funk Island, Research was supported by the Northern Cod Science Program, a Fisheries and Oceans/ NSERC Subvention and an NSERC Individual Operating Grant.

\section{LITERATURE CITED}

Aebischer, N. J., Coulson, J. C., Colebrook, J. M. (1990). Parallel long term trends across four marine trophic levels and weather. Nature 347: 753-755

Bailey, R. S., Furness, R. W., Gauld, J. A., Kunzlik, P. A. (1991). Recent changes in the population of the sandeel, Ammodytes marinus Raitt, at Shetland in relation to estimates of seabird predation. ICES mar. Sci. Symp. 193: 209-216

Barrett, R. T., Røv, N., Loen, J., Montevecchi, W. A. (1990). Diets of shags Phalacrocorax aristotelis and cormorants $P$. carbo in Norway and possible implications for gadoid stock recruitment. Mar. Ecol. Prog. Ser. 66: 205-218

Barry, J. P., Dayton, P. K. (1991). Physical heterogeneity and 
the organization of marine communities. In: Kolasa, J., Pickett, S. T. A. (eds.) Ecological heterogeneity. SpringerVerlag, Berlin, p. 270-320

Bayley, G. V., Hammersley, J. M. (1946). The 'effective' number of independent time observations in an autocorrelated time series. J. R. stat. Soc. 8: 184-197

Bertram, D. F., Kaiser, G. W. (1993). Rhinoceros auklets (Cerorhinca monocerata) nestling diet may gauge Pacific sandlance (Ammodytes hexapterus) recruitment. Can. J. Fish. Aquat. Sci. 50: 1908-1915

Black, G. A. P., Rowell, T. W., Dawe, E. G. (1987). Atlas and biology and distribution of the squids Illex illecebrosus and Loligo sealsi in the Northwest Atlantic. Spec. Publ. Can. Fish. Aquat. Sci.

Clarke, M. R. (1977). Beaks, nets and numbers. Symp. Zool. Soc. Lond. 38: 89-126

Coelho, M. L. (1985). Review of the influence of oceanographic factors on cephalopod distribution and life cycle. N. Atlant. Fish. Organ. Sci. Coun. Stud. 9: 47-57

Croxall, J. P. (1989). Use of indices of predator status and performance in CCAMLR fishery management. Sci. Comm. Conserv. Antarc. Mar. Liv. Resources Pap. 1989: 353-365

Dawe, E. G., Beck, P. C. (1985). Distribution and size of short finned squid (Illex illecebrosus) larvae in the northwest Atlantic from winter surveys in 1969, 1981 and 1982. J. NW Atlant. Fish. Sci. 6(2): 43-45

Dawe, E. G., Warren, W. G. (1992). Recruitment of short finned squid in the Northwest Atlantic Ocean and some environmental relationships. Cephalopod Biol. 2: 1-21

Diner, N., Masse, R. (1987). Fish school behaviour during echo survey observed by acoustic devices. C.M. ICES/P:30

Donahue, B. (1993). Fisheries access: licensing and registration - policy and statistical review, 1977-1992. Supply and Services Canada, Ottawa

Doubleday, W. G., Rivard, D. (eds.) (1981). Bottom trawl surveys. Can. Spec. Publ. Fish. Aquat. Sci. 66

Drinkwater, K. F., Myers, R. A., Pettipas, R. G., Wright, T. L. (1994). Climatic data for the northwest Atlantic: the position of the shelf/slope front and the northern boundary of the Gulf Stream between 50 W and 75 W, 1973-1992. Can. Data Rep. Hydrogr. Ocean Sci. 125

Duffy, D. C., Wilson, R. P., Wilson, M. P. (1987). Spatial and temporal patterns of diet in the cape cormorant off southern Africa. Condor 89: 830-834

Hatch, S. A., Sanger, G. A. (1992). Puffins as predators on juvenile pollack and other forage fish in the Gulf of Alaska. Mar. Ecol. Prog. Ser. 80: 1-14

Hislop, J. R. G., Harris, M. P. (1985). Recent changes in the food of young puffins Fratercula arctica on the Isle of May in relation to fish stocks. Ibis 127: 234-239

Hunt, G. L. Jr, Piatt, J. F., Erikstad, K. E. (1991). How do foraging seabirds sample their environment? Acta XX Cong. Int. Ornithol. 1990: 2272-2279

Hunt, G. L. Jr, Schneider, D. C. (1987). Scale-dependent processes in the physical and biological environment. In: Croxall, J. P. (ed.) Seabirds: feeding ecology and role in marine ecosystems. Cambridge University Press, Cambridge, p. 7-41

Hutchings, J. A., Myers, R. A., Lilly, G. R. (1993). Geographic variation in the spawning of Atlantic cod, Gadus morhua, in the northwest Atlantic. Can. J. Fish. Aquat. Sci. 50: $2457-2467$

Hurley, G. V. (1980a). An examination of criteria for short term forecasting of inshore abundance of squid (Illex illecebrosus) at Newfoundland. N. Atlant. Fish. Organ. Sci. Comm. Res. Doc. 80/II/5, Northwest Atlantic Fisheries Organization, Dartmouth
Hurley, G. V. (1980b). Recent developments in the squid, Illex illecebrosus, fishery of Newfoundland, Canada. U.S. Nat. Mar. Fish. Serv. 42: 15-22

Klages, N. T. W., Willis, A. B., Ross, G. J. B. (1992). Variability in the diet of the cape gannet at Bird Island, Algoa Bay, South Africa. In: Payne, A. I. L., Brink, K. U., Mann, K. H., Hilborn, R. (eds.) Benguela trophic functioning. S. Afr. J. mar. Sci. 12: 761-771

Lilly, G. R. (1991). Interannual variability in predation by cod (Gadus morhua) on capelin (Mallotus villosus) and other prey off southern Labrador and northeastern Newfoundland. ICES mar. Sci. Symp. 193: 133-146

Mann, K. H. (1993). Physical oceanography, food chains and fish stocks: a review. ICES J. mar. Sci. 50: 105-119

Monaghan, P., Uttley, J. D., Okill, J. D. (1989). Terns and sandeels: seabirds as predictors of changes in marine fish populations. J. Fish. Biol. 35: 339-340

Montevecchi, W. A. (1993). Birds as indicators of change in marine prey stocks. In: Furness, R. W., Greenwood, J. J. D. (eds.) Birds as environmental monitors. Chapman Hall, London, p. 217-266

Montevecchi, W. A., Berruti, A. (1991). Avian bio-indication of pelagic fishery conditions in the southeast and northwest Atlantic. Acta XX Cong. Int. Ornithol, 1990: 2246-2256

Montevecchi, W. A., Birt, V. L., Cairns, D. K. (1987). Dietary shifts of seabirds associated with local fisheries failures. Biol. Oceanogr. 5: 153-159

Montevecchi, W. A., Myers, R. A. (1992). Monitoring fluctuations in pelagic fish availability with seabirds. Can. Atlant. Fish. Sci. Advis. Comm. Res. Doc. 92/94. Northwest Atlantic Fisheries Organization, Dartmouth

Montevecchi, W. A., Ricklefs, R. E., Kirkham, I. R., Gabaldon, D. (1984). Growth energetics of nestling northern gannets. Auk 101: 334-341

Montevecchi, W. A., Tuck, L. M. (1987). Newfoundland birds: exploitation, study, conservation. Nuttall Ornithological Club, Cambridge, MA

Parsons, L. S. (1970). Northern range expansion of the Atlantic mackerel, Scomber scombrus, to Black Island, Labrador. J. Fish. Res. Bd Can. 27: 610-613

Schneider, D. C., Hunt, G. L. Jr (1984). A comparison of seabird diets and foraging distribution around the Pribilof Islands, Alaska. In: Nettleship, D. N., Sanger, G. A., Springer, P. F. (eds.) Marine birds: their feeding ecology and commercial fishery relationships. Canadian Wildlife Service, Ottawa, p. 86-95

Scott, W. B., Scott, M. G. (1988). Atlantic fishes of Canada. Can. Bull. Fish. Aquat. Sci. 219

Sokal, R. R., Rohlf, F. J. (1981). Biometry, 2nd edn. Freeman, San Francisco

Squires, H. J. (1957). Illex illecebrosus (LeSueur), in the Newfoundland fishing area. J. Fish. Res. Bd Can. 13: 693-728

Stobo, W. T., Moores, J. A., Maguire, J. J. (1982). The herring and mackerel resources on the east coast of Canada. Can. Tech. Rep. Fish. Aquat. Sci. 1081

Templemen, W., Fleming, A. M. (1953). Long term changes in hydrographic conditions and corresponding changes in the abundance of marine animals. A. Proc. int. Comm. NW Atlant. Fish. 3(5): 3-10

Thompson, K. R., Loucks, R. H., Trites, R. W. (1988). Sea surface temperature variability in the shelf-slope region of the Northwest Atlantic. Atmos. Ocean 26: 282-299

Vermeer, K., Westrheim, S. J. (1984). Fish changes in diets of nestling rhinoceros auklets and their implications. In: Nettleship, D. N., Sanger, G. A., Springer, P. F. (eds.) Marine birds: their feeding ecology and commercial fishery relationships. Canadian Wildlife Service, Ottawa, p. 96-105 